\title{
Quantification and characterization of Salmonella spp. isolates in sewage sludge with potential usage in agriculture
}

Flávio Krzyzanowski $\mathrm{Jr}^{1,2^{*}}$, Lincohn Zappelini ${ }^{1,2 \dagger}$, Solange Martone-Rocha ${ }^{2 \dagger}$, Milena Dropa ${ }^{2 \dagger}$, Maria Helena Matté ${ }^{2 \dagger}$, Flávia Nacache ${ }^{2 \dagger}$ and Maria Tereza Pepe Razzolini ${ }^{2+}$

\begin{abstract}
Background: This study aims to scrutinize Salmonella spp. and its serotypes in sewage sludge samples from wastewater treatment plants, and assesses the presence of virulence genes and antibiotics resistant to the profile. Samples $(n=54)$ were collected and analyzed in accordance with the EPA Method 1682/2006. For positive serological reaction, 40 strains were selected for PCR analyses and detection of spvC, invA and sseL virulence genes, plasmid presence and resistance to antibiotics.

Results: Salmonella spp. was detected in $38.9 \%$ of the samples collected ( $<0.006473$ to $12.19 \mathrm{MPN} / \mathrm{gTS}$ ). The most prevalent serotype was Salmonella Infantis. All Salmonella spp. $(n=35)$ presented at least one of the three virulence genes mentioned above and $40 \%$ harboured plasmids. Salmonella Typhimurium strains were isolated harbouring at least one of the following virulence genes: spvC, invA or ssel. Four Salmonella spp. isolates were resistant to tetracycline; three were resistant to trimethoprim-sulfamethoxazole, and one isolate was resistant to ciprofloxacin. Two Salmonella spp. strains presented multi resistance to antimicrobial agents.

Conclusions: The results obtained demonstrated that Salmonella spp. have been found in sewage sludge, thus it is essential to set measures to mitigate human health risks when it is intended to be applied on agricultural soils.
\end{abstract}

Keywords: Salmonella spp, Sewage sludge, Antimicrobial resistance, Plasmid presence, Virulence genes presence

\section{Background}

The employment of sewage sludge on agricultural fields has been recognized worldwide as a promising way to manage this kind of residue, as it can minimize environmental pollution, in addition to giving it useful destination, what is done at the Wastewater Treatment Plants (WWTP). None the less, careful consideration regarding its quality and impacts on human health ought to be given, since the presence of pathogens in sewage sludge, including Salmonella spp., have been documented in manifold studies [1-4].

In order to protect both human and environmental health, Brazilian legislation issued by Conselho Nacional

\footnotetext{
*Correspondence: fkjuniormeister@gmail.com

${ }^{\dagger}$ Equal contributors

'Instituto Federal de Educação, Ciência e Tecnologia de São Paulo - Brasil, Rua Pedro Vicente 625, 01109-010 São Paulo, Brazil

${ }^{2}$ School of Public Health of University of São Paulo-Brazil, Av. Dr Arnaldo 715, $1{ }^{\circ}$ andar, 01246-904 São Paulo, Brasil
}

\section{() Biomed Central}

do Meio Ambiente (Environmental National Council), which is a branch of the Federal Environmental Council, CONAMA N ${ }^{\circ} 375 / 2006$ - has classified sewage sludge in two distinct classes: A (unrestricted application) and B (restricted application). For class A, the maximum values for thermotolerant coliforms is $\leq 10^{3} \mathrm{MPN} / \mathrm{gTotal}$ Solids (TS), the total absence of Salmonella spp. in $10 \mathrm{~g}$ of total solids, followed by $<0.25$ helminth viable ova/gTS and $\leq 0.25$ enterovirus/g TS, while for class B the standards are $\leq 10^{6}$ MPN/gTS for thermotolerant coliforms and $<10$ helminth viable ova/gTS [5]. Some countries or some of their respective regions have been establishing microbiological and parasitological standards for biosolids, such as the USA legislation [6], the United Kingdom [7], Australia (South Australia, West Australia and EPA Victoria), Finland and New Zealand [8]. 
The employment of sewage sludge with no sanitary criteria or barriers, particularly in agricultural fields, intensifies the potential to disseminate such pathogen.

Of late, a worldwide increase in the number of outbreaks involving Salmonella spp. related to the fresh-cut produce industry and the consumption of fresh-cut vegetables has been observed. Such outbreaks are caused by a few Salmonella serotypes which have the capability to resist to environmental stresses, remaining viable for extended periods on field crops [9-11]. It has been observed that Salmonella can regrow in the soil and remain viable for more than two years after soil inoculation [12].

In a global survey conducted from 1990 to 1995, Salmonella Enteritidis, and Salmonella Typhimurium were considered to be the most isolated non-typhoid Salmonella in fifty-nine countries [13]. None of the less, in the city of São Paulo (Brazil), where surveillance studies indicated an increase in the prevalence of Salmonella Enteritidis both in clinical and environmental samples, whereas studies conducted in Agona, Ohio and Albany demonstrated the most isolated serotypes from sewage samples [14,15].

The presence of virulence genes such as $i n v A$ and $s s e L$, which are located, respectively, on the pathogenicity island I (SPI-1) and II (SPI-2), has been used as evidence of pathogenicity [16]. The virulence genes which compose SPI Pathogenicity Island are responsible for the entry of Salmonella spp. into host epithelial cells. The pathogenic genes presented in SPI-2 are related to modifications in host cell functions, being thus essential for survival and replication of Salmonella Enterica within host macrophages [17]. The $s p v C$ virulence gene, present in plasmids and/or chromosomes, strengthens the systemic proliferation of the pathogen and, furthermore, contributes to its replication in extra-intestinal sites [18]. The presence of these three virulence genes predicts overall pathogenicity, invasiveness and replication capabilities of Salmonella species.

Antimicrobial resistance patterns for typhoidal and non-typhoidal Salmonella are constantly changing, and the treatment of infections caused by multidrug resistant strains (MDR) poses a serious public health concern. A study conducted in Brazil with Salmonella spp. strains isolated from clinical specimens which were collected in each of the five Brazilian regions, detected that this microorganism presented low resistance to all antibiotics tested, except for cloranfenicol [19]. Later on, a study conducted by Medeiros et al. [20] with the participation of several Brazilian states, pointed out to the fact that all the 250 Salmonella strains which were previously isolated from chicken carcasses were resistant to at least one antibiotic, and that $53.2 \%$ of the samples assessed were MDR.
In the light of the fact that the use of sewage sludge on agricultural fields can be considered a way to spread such pathogen, and therefore risk the health of the population exposed, the aim of this study was to survey Salmonella spp. and its serotypes in sewage sludge samples from five WWTPs located in São Paulo metropolitan region (MRSP). In addition to so, we intended to search for the presence of virulence genes, plasmids, and antimicrobial resistance/resistant profiles in the isolated strains.

\section{Results}

In total, 54 samples were collected from the five WWTP sites throughout the 12 months of 2011, and analysed in order to observe Salmonella spp. presence. Table 1 shows Salmonella concentrations in sludge samples from each WWTP studied from January to December 2011. This bacterium was detected in 38.9\% (21/54) of all samples analysed. Bacteria concentration above $<0.006473 \mathrm{MPN} / \mathrm{g}$ TS (Detection Limit - DL) was detected in 38.9\% (21/54) of all samples analysed. The highest concentration of Salmonella spp. was found in WWTP 2, where counts ranged from DL $(<0.006473 \mathrm{MPN} / \mathrm{g}$ TS $)$ to $12.19 \mathrm{MPN} / \mathrm{g}$. The lowest Salmonella spp. concentration was found in WWTP 1 (0.75 MPN/g) and WWTP 5 (0.43 MPN/g), and no Salmonella spp. was isolated in WWTP 3.

Table 2 summarizes the results obtained via serology identification. Such results indicate the presence of virulence genes, plasmids, and antibiotic resistance in Salmonella strains which were previously isolated from sewage sludge. Out of the 307 isolations, 40 were selected and subjected to serological typing. Five strains could not be serotyped. The most prevalent serotype among the strains which were submitted to serotype procedure was

Table 1 Concentration of Salmonella spp. (MPN/g TS) in sewage sludge samples collected from the five WWTPs in 2011

\begin{tabular}{llllll}
\hline Date & WWTP 1 & WWTP 2 & WWTP 3 & WWTP 4 & WWTP 5 \\
\hline Jan & $<0.006473$ & $<0.006473$ & $<0.006473$ & 0.43 & $<0.006473$ \\
Feb & $<0.006473$ & 1.74 & $<0.006473$ & 0.49 & 0.43 \\
Mar & $<0.006473$ & 3.72 & NP & $<0.006473$ & $<0.006473$ \\
Apr & $<0.006473$ & 6.03 & $<0.006473$ & 0.21 & $<0.006473$ \\
May & $<0.006473$ & 4.81 & $<0.006473$ & $<0.006473$ & $<0.006473$ \\
Jun & $<0.006473$ & 5.63 & $<0.006473$ & NP & $<0.006473$ \\
Jul & $<0.006473$ & 2.28 & NP & 1.32 & $<0.006473$ \\
Aug & $<0.006473$ & 12.20 & NP & $<0.006473$ & $<0.006473$ \\
Sep & $<0.006473$ & 3.29 & NP & 0.69 & $<0.006473$ \\
Oct & $<0.006473$ & 1.66 & $<0.006473$ & 0.76 & $<0.006473$ \\
Nov & 0.75 & 5.74 & NP & 0.85 & $<0.006473$ \\
Dec & $<0.006473$ & 4.45 & $<0.006473$ & 1.86 & $<0.006473$ \\
\hline NP Nof Peformed. & & & &
\end{tabular}

$\mathrm{NP}=$ Not Performed. 
Table 2 Serological identification, presence of virulence genes, plasmids, and resistance to antibiotics regarding Salmonella strains

\begin{tabular}{|c|c|c|c|c|c|c|}
\hline \multirow{2}{*}{$\begin{array}{l}\text { Sample } \\
\text { source }\end{array}$} & \multirow[t]{2}{*}{ Serovars } & \multicolumn{3}{|c|}{ Presence of virulence genes } & \multirow[t]{2}{*}{ Plasmid } & \multirow[t]{2}{*}{ Antibiotic resistence } \\
\hline & & $\overline{i n v A}$ & ssel & spvC & & \\
\hline WWTP 2 & Infantis & + & + & - & + & $S$ \\
\hline WWTP 2 & Infantis & + & + & - & - & S \\
\hline WWTP 2 & Infantis & + & + & - & - & S \\
\hline WWTP 2 & Infantis & + & + & - & - & S \\
\hline WWTP 4 & Infantis & + & + & - & - & S \\
\hline WWTP 4 & Infantis & + & + & - & - & S \\
\hline WWTP 2 & Agona & + & + & - & - & S \\
\hline WWTP 2 & Agona & + & + & - & - & AMP,CIP \\
\hline WWTP 2 & Agona & + & + & - & - & S \\
\hline WWTP 2 & Agona & + & + & - & - & S \\
\hline WWTP 4 & Agona & + & + & - & - & S \\
\hline WWTP 2 & Anatum & + & + & - & + & TET,SUT \\
\hline WWTP 2 & Anatum & + & + & - & + & TET,SUT \\
\hline WWTP 2 & Anatum & + & + & - & - & S \\
\hline WWTP 4 & Corvalis & + & + & - & + & S \\
\hline WWTP 4 & Corvalis & + & + & - & + & S \\
\hline WWTP 4 & Corvalis & + & + & - & + & S \\
\hline WWTP 2 & Mbandaka & + & + & - & - & S \\
\hline WWTP 4 & Mbandaka & + & + & - & - & S \\
\hline WWTP 4 & Mbandaka & + & + & - & - & S \\
\hline WWTP 4 & Typhimurium & + & + & - & + & TET, AMP, SUT \\
\hline WWTP 5 & Typhimurium & + & + & + & + & S \\
\hline WWTP 5 & Typhimurium & + & + & + & + & S \\
\hline WWTP 1 & München & + & + & - & + & CAZ, TET, ATM, CTT, COM \\
\hline WWTP 2 & München & - & + & - & + & S \\
\hline WWTP 4 & Salamae & + & + & - & - & S \\
\hline WWTP 4 & Salamae & + & + & - & - & S \\
\hline WWTP 4 & Give & + & + & - & - & S \\
\hline WWTP 4 & Javiana & + & + & - & - & S \\
\hline WWTP 2 & Minnesota & + & + & - & - & S \\
\hline WWTP 2 & Molade & - & + & - & + & S \\
\hline WWTP 4 & Newport & + & + & - & - & S \\
\hline WWTP 2 & Ohio & + & + & - & + & S \\
\hline WWTP 2 & Oranienburg & + & + & - & - & S \\
\hline WWTP 2 & Ouakan & + & + & - & + & $S$ \\
\hline
\end{tabular}

(+) presence, (-) absence; S-susceptible; AMP: ampicillin; CTT: cefotetan; TET: tetracycline; CIP: ciprofloxacin; SUT: sulfametoxazol; CAZ: ceftazidime; ATM: aztreonam; COM: cefepime.

Salmonella Infantis, where 6 out of the 35 strains analysed could be classified as such, followed by $S$. Agona with $14.3 \%(5 / 35)$, and $8.6 \%(3 / 35)$ in regard to $S$. Anatum, S. Corvallis, S. Mbandaka, and S. Typhimurium; $5.7 \%$ $(2 / 35)$ in regard to $S$. Müchen, S. Salamae, and 2.8\% (1/35) in regard to $S$. Give, $S$. Javiana, $S$. Minnesota, $S$. Molade, $S$. Newport, $S$. Ohio, $S$. Oranienburg, and $S$. Ouakam.

The results referring to the detection of virulence genes revealed that all Salmonella spp. isolated strains previously analysed presented at least one of the $s p v C$, 
invA, and sseL genes. Two strains (Salmonella Molade and Salmonella Muechen) presented negative results for invA gene, and two strains of Salmonella Typhimurium present at the $\operatorname{spvC}$ gene. From the 35 isolates subjected to plasmid extraction, $14(40 \%)$ presented at least one plasmid.

Antimicrobial susceptibility tests revealed that $14.2 \%$ $(3 / 35)$ of the strains were resistant to two antimicrobial agents, and just two strains 2/35 (5.7\%) were MDR. All isolates were susceptible to cefotetan, imipenem, meropenem, and ertapenem (Table 2).

Figure 1 presents the image of agarose gels for PCR identification of Salmonella spp. previously isolated which were obtained from sewage sludge. In these strains, the presence of virulence genes and plasmidial profile were analysed. The identification of 40 isolates by PCR resulted in 36 strains containing the 429 bp band expected for all organisms identified as Salmonella spp. Three presented the $429 \mathrm{bp}$ band in addition to the 620 bp band expected for Salmonella Typhimurium. Salmonella Enteritidis was not identified in this study, and four isolates were not identified as belonging to Salmonella group. As for plasmids, these extracromossomal elements were observed in 14 (40\%) of the Salmonella strains subjected to serotyping, including Salmonella Typhimurium.

\section{Discussion}

This study aims to present the level of Salmonella contamination in sewage sludge from WWTPs located in the most populated Brazilian metropolitan area. Data concerning the presence and concentration of such pathogen in sewage sludge are scarce in Brazil. Thus, the results herein reported could constitute an informational dataset, which would be used in order to give further support to interventional measures developed by sanitary authorities and also to the process of establishing guidelines for sludge usage on agricultural fields.

None of the less, we have also observed a huge difference in Salmonella spp. concentration amongst the five WWTPs assessed. In WWTP 1, WWTP 3, and WWTP 5, lime stabilizations were performed, which, according to Bean et al. [21], increases pH values up to 13, thus possibly eliminating all bacteria. In WWTP 2 and 4 where lime stabilization was not performed, Salmonella spp. concentration was higher if in comparison with WWTP 1,3 , and 5 .

It is quite common to find such differences among results concerning the presence or concentration of Salmonella spp. in sewage sludge worldwide, even in those which undergo the same treatment process (mesophilic anaerobic digestion). In the present study, the frequency of positive samples were above DL $(<0.006473 \mathrm{MNP} / \mathrm{g})$ in

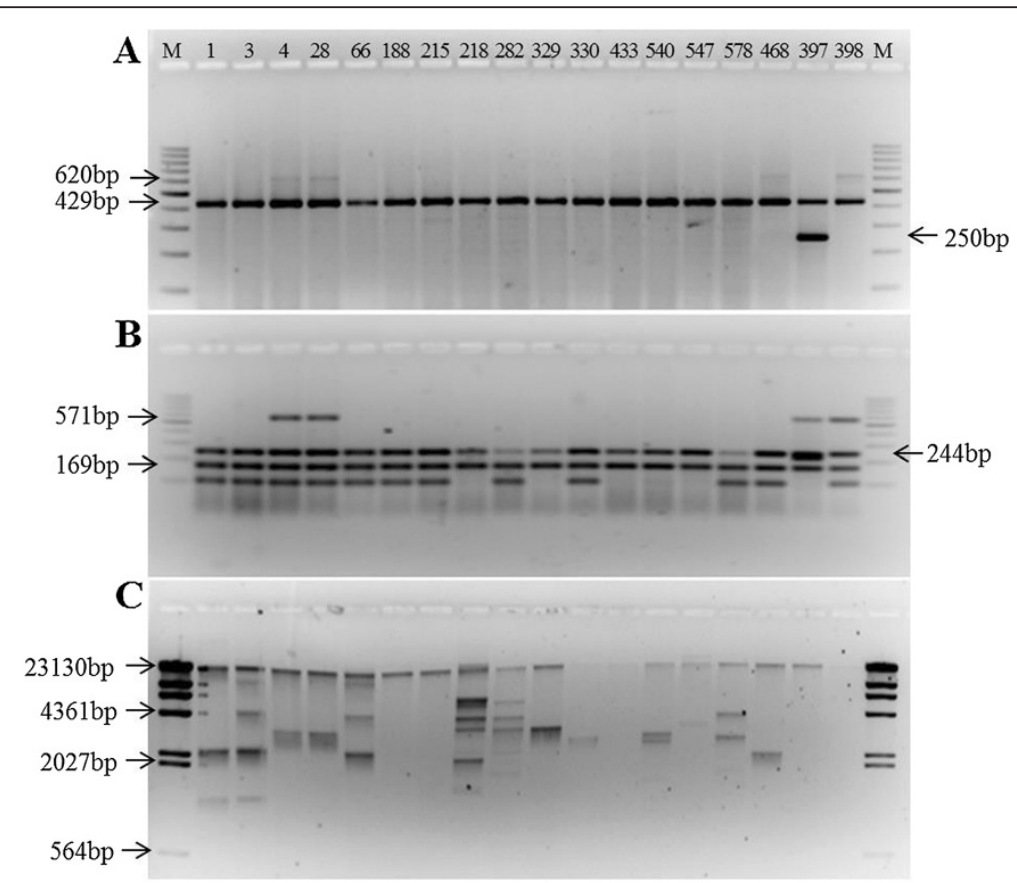

Figure 1 Image of agarose gels for PCR identification of Salmonella spp. isolates from sewage sludge, presence of virulence genes and plasmidial profile. A- Identification of Salmonella spp. and serotypes Salmonella Typhimurium e Salmonella Enteriditis; B- Detection of virulence genes; C- Plasmidial profile; Strains 397 and 398: positive control for Salmonella Enteriditis and Salmonella Typhimurium, respectively; M- molecular weight markers. 
$38.9 \%(21 / 54)$ of the samples analyzed, which was below the figures derived from other studies [22] and [23], which registered $92-100 \%(\mathrm{n}=91)$ and 58\% ( $\mathrm{n}=24)$, respectively. The highest concentration of Salmonella spp. was found in WWTP $2\left(1.2 \times 10^{1} \mathrm{MPN} / \mathrm{g}\right)$, which is in agreement with the review previously carried out by Sidhu and Toze [3], wherein the concentration usually varied from $1.1 \times 10^{1}$ to $5.9 \times 10^{3} \mathrm{MPN} / \mathrm{g}$ TS. Wong et al. [24], on the contrary, found lower concentrations than the ones from the above mentioned studies, that is, ranging from 0.487 $\mathrm{MPN} / 4 \mathrm{~g}$ to $0.954 \mathrm{MPN} / 4 \mathrm{~g}(0.122-0.238 \mathrm{MPN} / \mathrm{g})$ in sludge from a WWTP in Michigan (USA). Such differences may be explained by the complex chemical sludge composition which differs from one country to another, type of treatment applied, regrowth or the presence of growth inhibitory factors, and population epidemiological profile [23]. Although distinct epidemiological studies have indicated the presence of Salmonella Enteritidis in sewage sludge, in the present study such serotype has not been detected. The absence of such specific serotype could be explained due to the limited number of strains serotyped. Similar results were noticed in Sweden [23]. Salström, in 2006, stated that such results could be due to the fact that this serotype is best adapted to human and animal hosts rather than to stressful environmental conditions [23]. None of the less, the presence of several serotypes in sewage sludge after outbreaks related to the ingestion of raw fruits and vegetables, such as $S$. Infantis, S. Newport, S. Javiana, S. Oranienburg, S. Mbandaka, S. Anatum, S. Müenchen, and S. Typhimurium [9,25-27], was observed. Furthermore, serotypes $S$. Newport and $S$. Typhimurium have a remarkable capacity to form a biofilm on leaves [28] and then to invade various tissues of plants [29].

The presence of $s p \nu C$ gene was found in only two out of the three Salmonella Typhimurium isolated strains, harbouring also invA and sseL genes. Peterson et al. [30] reported that up to that moment, the spvC gene had been found only in five Salmonella strains: $S$. Cholerasuis, S. Dublin, S. Enteritidis, and S. Typhimurium. Thus, the Salmonella Typhimurium strains mentioned in this study could represent a threat, as three virulence genes were detected even after the sewage sludge treatment.

From the 35 strains tested, 33 harboured sseL as well as the $i n v A$ virulence genes, however two strains (Salmonella Molade and Salmonella München), did not harbour the latter virulence gene. The $i n v A$ gene is widely recognised as a genetic marker for Salmonella enterica strains, as so can be found in almost all strains, being even used for PCR identification in this group [31]. Instead, upon assessing 630 different Salmonella enterica strains, Rahn et al. [32], found that $99.4 \%$ of those strains harboured the inv $A$ gene. Therefore, although found in the group related to the present study, the presence of $i n v A$ gene is not universal.
Forty per cent of the 35 strains identified in this study presented plasmids (Table 2). According to Rychlik et al. [33], high molecular weight plasmids (above $20 \mathrm{~Kb}$ ) are usually related to virulence genes or as resistance to antimicrobial agents; and low weight plasmids have not yet been fully comprehended, however, some of them could be related as resistant to heavy metals and also to other substances found in the environment. Although the isolation techniques performed in our study do not distinguish between high and low molecular weight plasmids, it was possible to observe the presence of such elements in $40 \%$ of the strains, including two Salmonella Typhimurium, which presented the $s p v C$ gene. The existence of plasmids in Salmonella strains in this study might come as a result in regard to the presence of heavy metals and high sulphur concentrations that are commonly present in São Paulo wastewaters and sewage sludge [34,35].

Concerning antimicrobial resistance, out of the five strains which were resistant to two or more drugs, four harboured plasmids, and one Salmonella Agona strain was resistant to two antimicrobial agents, presenting no plasmid at all (Table 2). Singh et al. [36] perceived that the presence of plasmids is not mandatory for the occurrence of antimicrobial drug resistance in Salmonella Enterica strains, once such resistant genes can also be found in chromosomes.

The results demonstrated in this research show that $14.2 \%(3 / 35)$ of the strains were resistant to two antimicrobial agents, and 5.7\% (2/35) were MDR. Similar results were found by Sahlström et al. [23] - where 12\% $(12 / 101)$ of Salmonella isolates were resistant to at least one antimicrobial agent, and $7 \%$ (7/101) were MDR strains. Such results are quite different from those related to other studies previously conducted in Brazil, where Salmonella strains from human and non-human sources presented higher resistance to antimicrobial agents. In Rio de Janeiro, Fonseca et al. [37] isolated 35 Salmonella Infantis samples derived from stools of hospitalized children and found that 34 strains were resistant to at least two antimicrobial agents.

Studies conducted by Oliveira et al. [38] and Medeiros et al. [20] found in a farm strains of Salmonella in animal waste which were resistant to antibiotics, hence demonstrating that such kind of strain is circulating freely in the environment, and such fact can be considered as a crucial concern in case sewage sludge is used in agriculture.

Although the present study demonstrates a vast number of susceptible strains, the presence of an ESBL-producing and ciprofloxacin-resistant Salmonella (Agona) is worrisome. Since resistance to this antibiotic has increased and so has the production of ESBL [39], and also seeing that such is the alternative antibiotic 
with the aim of controlling MDR strains, treatment options are now limited.

Eventually, we also ought to take into account that some studies have presented the ability Salmonella spp. presents when it comes to regrowth in soil, internalization phenomena and its growth within plants tissues, as well as its capacity to survive for long periods in soil and crops [40-42]. Therefore, its presence must be considered as a major concern, even if such is found in low concentrations.

\section{Conclusions}

The results obtained in this study demonstrate that several genres of Salmonella are circulating in the environment, including MDR strains, therefore they can easily be found in sewage sludge. Although Salmonella Enteritidis strains were not isolated in this study, the serotypes herein mentioned are implicated in several worldwide outbreaks related to these bacteria. Moreover, certain virulence factors were found in three samples of Salmonella Typhimurium which harboured $i n v A$, sseL and $s p v C$. Therefore in order to avoid the spreading of such bacteria through the consumption of fresh products the application of sewage sludge in agricultural soils should only be allowed with the implementation of sanitary barriers, under the supervision of environmental and health authorities, such as different types of sewage sludge stabilizations, already present in other countries.

\section{Methods}

\section{Sampling}

Sludge samples were collected from five Wastewater Treatment Plants (WWTP) located in a Brazilian densely populated metropolitan region. The treatment process which was used in all WWTPs was activated sludge with mesophilic anaerobic sludge digestion. Table 3 shows the operational characteristics of each WWTP provided by Sabesp [43], such as sewage flow rates $(\mathrm{L} / \mathrm{s})$, generated sludge (Ton/d), and chemical conditioning.

Sampling was performed monthly in each WWTP in accordance with EPA's recommendations [44] from January 2011 to December 2011. Samples $(n=54)$ were collected from a sludge pile after the dewatering process and stored in sterile plastic bottles which were kept chilled during transportation and analyzed within a 24-hour period.

\section{Salmonella spp. isolation}

Salmonella spp. isolation and enumeration were performed according to the EPA Method 1682 [44]: Salmonella in Sewage Sludge (Biosolids) Modified Semisolid Rappaport-Vassiliadis (MSRV). This method is based on "the most probable number technique" (MPN). Briefly, prior to inoculation, $30 \mathrm{~g}$ of sewage sludge was diluted with buffered water and homogenized in a mixer for two
Table 3 Sewage flow rates (L/s), generated sludge (Ton/d), and chemical conditioning applied to the five WWTPs

\begin{tabular}{llll}
\hline WWTP & $\begin{array}{l}\text { Sewage } \\
\text { flow }(\mathbf{L} / \mathbf{s})\end{array}$ & $\begin{array}{l}\text { Generated } \\
\text { sludge (Ton/d) }\end{array}$ & Chemical conditioning \\
\hline 1 & 1.89 & 69.0 & Lime + Ferric chloride \\
2 & 10.19 & 316.0 & Ferric chloride + polymers \\
3 & 2.48 & 73.7 & Lime + Ferric chloride + Polymers \\
4 & 0.80 & 14.3 & Ferric chloride + polymers \\
5 & 0.85 & 41.0 & Lime + Ferric chloride \\
\hline
\end{tabular}

minutes. Subsequently, volumes of 20,10 , and $1 \mathrm{~mL}$ were inoculated in three series of five tubes containing Tryptic Soy Broth Medium (TSB) (Difco ${ }^{\circ}$, Detroit, MI,USA) and incubated at $36^{\circ} \mathrm{C}$ for 24 hours.

Subsequent to incubation, six drops $(30 \mu \mathrm{L})$ from each tube were transferred to selective MSRV medium (Difco ${ }^{\circ}$, Detroit, MI, USA) added with novobiocin (Difco ${ }^{\circ}$, Sparks, MD, USA) and malachite green in order to inhibit nonSalmonella species while permitting most Salmonella species to grow. MSRV plates were incubated at $42^{\circ} \mathrm{C}$ for 18 hours. Thereafter, colonies with "whitish halo" were transferred to Xylose-Lysine Desoxycholate agar (XLD) (Difco", Detroit, MI, USA) and incubated at $36^{\circ} \mathrm{C}$ for 24 hours. The existence of typical colonies could be confirmed by the usage of Lysine-Iron agar (LIA) (Difco', Detroit, MI, USA), Triple Sugar iron agar (TSI) (Difco ${ }^{\circ}$, Detroit, MI, USA), and of urea broth, followed by positive serological typing through the usage of poly $\mathrm{O}$ and poly $\mathrm{H}$ antisera. Determination of total solids (\% dry weight) was performed according to USEPA [44] and used to calculate MPN/g dry weight. Salmonella spp. density was reported in MPN/4 g of dry weight.

In order to determine circulating serotypes, 40 Salmonella spp isolated strains representing all samples previously examined were selected from both lowest and highest dilution of all positive samples from the five WWTPs. For serotyping, the strains were sent to the Enteropathogens Laboratory from "Instituto Adolfo Lutz", which is a branch of São Paulo State Department of Health.

\section{Salmonella spp. PCR identification}

From the 307 isolates with positive serological reaction, 40 were further tested through PCR. DNA was extracted according to the method described by Chapman et al. [45] and amplification was performed with the set of primers described by Soumet et al. [46].

Briefly, amplifications were performed on $5 \mu \mathrm{l}$ of the DNA samples which were previously extracted. Those samples were added to a mix $(20 \mu \mathrm{l})$ consisting of $5 \mu \mathrm{l}$ of $5 \times$ Gotaq buffer, $0.6 \mu \mathrm{mol}$ of each primer (Invitrogen Corp - California USA), $200 \mu \mathrm{mol}$ of dNTP (Thermo Fisher Scientific Inc.), and 1U of GOTaq Polymerase 
Table 4 PCR Primers were used for Salmonella spp. identification and virulence genes detection

\begin{tabular}{|c|c|c|c|c|}
\hline Target & Primers & Primers sequence & Band size & Reference \\
\hline \multirow[t]{6}{*}{ Identification } & ST11 & GCCAACCATTGCTAAATTGGCGCA & $429 \mathrm{pb}$ & {$[38]$} \\
\hline & ST15 & GGTAGAAATTCCCAGCGGGTACTGG & & \\
\hline & Fli15 & CGGTGTTGCCCAGGTTGGTAAT & $620 \mathrm{pb}$ & \\
\hline & Typ04 & ACTCTTGCTGGCGGTGCGACTT & & \\
\hline & S1 & GCCGTACACGAGCTTATAGA & $250 \mathrm{pb}$ & \\
\hline & \$4 & ACCTACAGGGGCACAATAAC & & \\
\hline \multirow[t]{6}{*}{ Virulence } & SPVC-1 & ACTCCTTGCACAACCAAATGCGGA & $571 \mathrm{pb}$ & [25] \\
\hline & SPVC-2 & TGTCTTCTGCATTTCGCCACCATCA & & \\
\hline & INVA-1 & ACAGTGCTCGTTAACGACCTGAAT & $244 \mathrm{pb}$ & \\
\hline & INVA-2 & AGACGACTGGTACTGATCGATAAT & & \\
\hline & ssel F & TTCCGCGACAACCGACCTTTCTAA & $169 \mathrm{pb}$ & \\
\hline & ssel R & TTCTTGAACCAGACCTTGCGTTGC & & \\
\hline
\end{tabular}

ST11/ST15-amplifying sequences of Salmonella sp; S1/S4-amplifying sequences of a Salmonella Enteritidis phage type 4 strain; Fli15/Typ04-amplifying sequences of Salmonella Typhimurium strain.

(Promega Inc.- Madinson, WI). Three sets of primers were used: ST11-ST15, specific for genus Salmonella; S1-S4 specific for Salmonella Enteritidis virulence genes; and Fli15-Typ04, which is a specific primer used to identify fliC genes only found in Salmonella Typhimurium. PCR reactions were carried out in a Mastercycler Thermocycler (Eppendorf - Hamburg, Germany). Primer sequences are described in Table 4.

\section{Detection of virulence genes}

The 40 previously selected isolates were tested in order

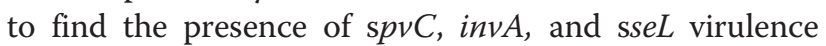
genes, which are in accordance to Peterson et al. [30]. Within a $25 \mu \mathrm{l}$ reaction volume, the following quantities were added: $5 \mu \mathrm{l}$ of DNA template, $5 \mu \mathrm{l}$ of $5 \times$ Gotaq buffer, $0.3 \mu \mathrm{mol}$ of each primer (Bioneer Oligo Synthesis Report - Korea), $200 \mu \mathrm{mol}$ of dNTP (Thermo Fisher Scientific Inc.), and $1 \mathrm{U}$ of GOTaq Polymerase (Promega Inc.- Wisconsin -USA) (Table 4).

\section{Electrophoresis}

PCR products were performed by electrophoresis using a $3.0 \%$ agarose gel prepared with $1 \times$ TAE buffer and stained with ethidium bromide. A 100 bp DNA Ladder Plus (Thermo Fisher Scientific Inc.) was included as a size marker. Gel images were obtained via UV transillumination and captured by a gel documentation system (Epi Chemi II Darkroom and Software Labworks - UVP).

\section{Plasmid detection}

Plasmid extraction was carried out by using a Wizard PlusSV Minipreps DNA Purification System commercial kit (Promega Inc.- Wisconsin -USA) using $2 \mathrm{~mL}$ of overnight culture according to the manufacturer's instructions. Plasmids were recovered in $100 \mu \mathrm{L}$ of nuclease-free water and stored at $20^{\circ} \mathrm{C}$. Prior to plasmid separation by electrophoresis, the material was heated for 15 minutes at $65^{\circ} \mathrm{C}$ and then maintained in ice bath for five minutes. The same process was conducted with a Hind III marker.

Plasmids were undergone electrophoresis in 1.0\% agarose gel for 3 hours at $3.0 \mathrm{~V} / \mathrm{cm}$ along with a molecular Hind III weight marker (Thermo Fisher Scientific Inc.). The gel was stained by using ethidium bromide $(10 \mathrm{mg} / \mathrm{ml})$, visualised under ultraviolet light and captured by Epi Chemi II Darkroom, and UVP BioImaging Systems.

\section{Antimicrobial susceptibility testing}

The 40 selected Salmonella spp. isolates were submitted to antimicrobial susceptibility tests by using the Kirby-Bauer disk-diffusion technique according to CLSI [47] recommendations. The antibiotics used were as follows: ciprofloxacin $(5$ $\mu \mathrm{g})$; tetracycline $(30 \mu \mathrm{g})$; trimethoprim-sulfamethoxazole (25 $\mu \mathrm{g})$; cefotetan $(30 \mu \mathrm{g})$; cefotaxime $(30 \mu \mathrm{g})$; ceftazidime (30 $\mu \mathrm{g})$; cefepime $(30 \mu \mathrm{g})$; aztreonam $(30 \mu \mathrm{g})$; imipenem (10 $\mu \mathrm{g}) ;$ meropenem $(10 \mu \mathrm{g})$; and ertapenem $(10 \mu \mathrm{g})$. In the case of resistance to $\beta$-lactams, further tests for enzyme production were performed [48]. Interpretation of inhibition zones was carried out by using CLSI [49] criteria.

\section{Competing interests}

The authors declared that they have no competing interests.

\section{Authors' contributions}

FK, LZ, SM, MH and MT contributed to the project design, lab works, collection of data, analysis of data, and drafting of manuscript. MD and FN contributed to the antimicrobial resistance tests and drafting of manuscript. All authors have read and approved the final version of this manuscript.

\section{Acknowledgements}

We would like to give thanks to the Coordination of Improvement of Higher Education-CAPES- for providing us with scholarships and also to Fundação de Amparo à Pesquisa do Estado de São Paulo- FAPESP - for its financial support (2010/05664-6). 
Received: 21 August 2013 Accepted: 2 October 2014

Published online: 22 October 2014

\section{References}

1. Horswell J, Ambrose V, Clucas L, Leckie A, Clinton P, Speir TW: Survival of Escherichia coli and Salmonella spp. after application of sewage sludge to a Pinus radiata forest. Journal of Applied Microbiology 2007, 103:1321-1331.

2. Iranpour R, Cox H: Recurrence of Fecal Coliforms and Salmonella Species in Biosolids Following Thermophlolic Anaerobic Digestion. Water Environment Research 2006, 78(9):1005-1012.

3. Sidhu JPS, Toze SG: Human pathogens and their indicators in biosolids: A literature review. Environment International 2009, 35:187-201.

4. Viau E, Bibby K, Paez-Rubio T, Peccia J: Toward a consensus view on the infectious risks associated with land application of sewage sludge. Environmental Science \& Technology 2011, 45:5459-5469.

5. Brasil: CONAMA. - Conselho Nacional do Meio Ambiente (Brasil). Resolução $n^{\circ} 375$, de 29 de agosto de 2006, Define critérios e procedimentos para o uso agrícola de lodos de esgoto gerados em estações de tratamento de esgoto sanitário e seus produtos derivados, e dá outras providências. Retificada pela Resolução n 380, de 2006. - Data da legislação: 29/08/2006 - Publicação DOU n 167, de 30/08/2006, pág. 141-146 de 29/08/2006. 2006. Online at: http://www.mma. gov.br/port/conama/legiabre.cfm? (accessed 13th May 2012).

6. USEPA (US Environemntal Protection Agency). United States Environmental Protection Agency: A guide to the biosolids risks assessments for the EPA Part 503 rule. 1997. http://water.epa.gov/scitech/wastetech/biosolids/upload/fr. (acessed in 22nd September 2010).

7. HMSO. Her Majesty Stationary Office: Statutory Instrument $N^{0}$ 1263. The sludge (use in agriculture) Regulation. London. 1989. Available at http://www.legislation. gov.uk/uksi/1989/1263/contents/made (accessed on 13 March 2014).

8. UN-HABITAT. United Nations Human Settlements Programme: Global Atlas of excreta, wastewater sludge, and biosolids management: Moving forward the sustainable and welcome uses of a global resource. Nairobi, KE; 2008. Avaiable at http://mirror.unhabitat.org/pmss/listltemDetails.aspx?publicationID=2551 (acessed on 20 September 2010).

9. Beuchat LR: Ecological factors influencing survival and growth of human pathogens on raw fruits and vegetables. Microbes and Infection 2002, 4:413-423.

10. Brandl TM: Fitness of human enteric pathogens on plants and implications for food safety. Annual Review of Phytophathology 2006, 44:367-392.

11. Francis GA, Gallone A, Nychas GJ, Sofos JN, Colelli G, Amodio ML, Spano G: Factors affecting quality and safety of fresh-cut produce. Critical Reviews in Food Science and Nutrition 2012, 52(7):595-610.

12. Nicholson FA, Groves SJ, Chambers BJ: Pathogen survival during livestock manure storage and following land application. Bioresource Technology 2005, 96:135-143.

13. Herikstad H, Motarjemi $Y$, Tauxe RV: Salmonella surveillance: a global survey of public health serotyping. Epidemiology \& Infection 2002, 129:1-8.

14. Fernandes SA, Tavechio AT, Ghilardi ACR, Dias AMG, Almeida IAZC, Melo LCV: Salmonella serotypes isolated from human in Sao Paulo State, Brazil, 1996-2003. Revista do Instituto de Medicina Tropical de São Paulo 2006, 48(4):179-184

15. Tavechio AT, Ghilardi ACR, Peresi JTM, Fuzihara EKY, Jakaba M, Fernandes AS: Salmonella Serotypes Isolated from Nonhuman Sources in São Paulo, Brazil, from 1996 through 2000. Journal of Food Protection 2002, 65(6):1041-1044.

16. Zou W, Al-Khaldi SF, Brahan WS, Han T, Fuscoe JC, Han J, Foley SL, Xu J, Fang $H$, Cerniglia CE, Nayak R: Microarray analysis of virulence gene profiles in Salmonella serotypes from food/food animal environment. Journal of Infection in Developing Countries 2011, 5(Suppl 2):S94-S105.

17. Eswarappa SM, Janice J, Nagarajan AG, Balasundaram SV, Karnam G, Dixit NM, Chakravortty D: Differentially Evolved Genes of Salmonella Pathogenicity Islands: Insights into the Mechanism of Host Specificity in Salmonella. PLOS ONE 2008, 3(12):e3829.

18. Zou M, Keelara S, Thakur S: Molecular Characterization of Salmonella enterica Serotype Enteritidis Isolates from Humans by Antimicrobial Resistance, Virulence Genes and Pulsed-Field Gel Electrophoresis. Foodborne Pathogens and Disease 2012, 9(3):232-238.

19. Oplustil CP, Nunes R, Mendes C: Multicenter Evaluation of Resistance Patterns of Klebsiella pneumoniae, Escherichia coli. Salmonella spp. and Shigella spp. isolated from Clinical Specimens in Brazil. Brazilian Journal of Infectious Diseases 2001, 5(1):8-12
20. Medeiros MAN, Oliveira DCN, Rodrigues DP, Freitas DRC: Prevalence and antimicrobial resistance of Salmonella in chicken carcasses at retail in 15 Brazilian cities. Revista Panamericana de Salud Pública 2011, 30 (6):555-560.

21. Bean $\mathrm{CL}$, Hansen JJ, Margolin AB, Balkin H, Batzer G, Widmer G: Class B Alkaline Stabilization to Achieve Pathogen Inactivation. International Journal of Environmental Research and Public Health 2007, 4(1):53-60.

22. Jones PW, Rennison LM, Lewin VH, Redhead DL: The occurrence and significance to animal health of salmonellas in sewage sludges. Journal of Hygiene Cambridge 1980, 84:47-62.

23. Sahlström $L$, Jong $B$, Aspan A: Salmonella isolated in sewage sludge traced back to human cases of salmonellosis. Letters in Applied Microbiology. 2006, 43:46-52.

24. Wong K, Onan BM, Xagoraraki I: Quantification of enteric viruses, pathogen indicators, and Salmonella bacteria in class B anaerobically digested biosolids by culture and molecular methods. Applied and Environmental Microbiology 2010, 76(19):6441-6448.

25. Harris LJ, Farber JN, Beuchat LR, Parish ME, Suslow TV, Garrett EH, Busta FF: Outbreaks associated with fresh produce: incidence, growth, and survival of pathogens in fresh and fresh- cut produce. Comprehensive Reviews in Food Science and Food Safety 2003, 2(Supplement):79-141.

26. Center for Disease Control and Prevention. [http://www.cdc.gov/salmonella/ live-poultry-05-12/index.html]. (accessed on 13 March 2014).

27. Heaton JC, Jones K: Microbial contamination of fruit and vegetables and the behaviour of enteropathogens in the phyllosphere: a review. Journal of Applied Microbiology 2008, 104:613-626.

28. Kroupitski Y, Pinto R, Brandl MT, Belausov E, Sela S: Interactions of Salmonella enterica with lettuce leaves. Journal of Applied Microbiology 2009, 106:1876-1885.

29. Hirneisen KA, Sharma M, Kniel KE: Human Enteric Pathogen Internalization by Root Uptake into Food Crops. Foodborne Pathogens and Disease 2012, 9(5):397-405.

30. Peterson G, Gerdes B, Berges J, Nagaraja TG, Frye JG, Boyle DS, Narayanan S: Development of microarray and multiplex polymerase chain reaction assays for identification of serotypes and virulence genes in Salmonella Enterica of human or animal origin. Journal of Veterinary Diagnostic Investigation 2010, 22(4):559-569.

31. Chiu CH, Ou JT: Rapid Identification of Salmonella Serovars in Feces by Specific Detection of Virulence Genes, invA and spvC, by an Enrichment Broth Culture-Multiplex PCR Combination Assay. Journal of Clinical Microbiology 1996, 34(10):2619-2622.

32. Rahn K, De Grandis SA, Clarke RC, McEwen SA, Galin JE, Ginocchio C, Curtiss $R$, Gyles CL: Amplification of an invA gene sequence of Salmonella typhimurium by polymerase chain reaction as a specific method of detection of Salmonella. Molecular and Cellular Probes 1992, 6:271-279.

33. Rychlik I, Gregorova D, Hradecka H: Distribution and function of plasmids in Salmonella enterica. Veterinary Microbiology 2006, 112:1-10.

34. Rangel OJP, Silva CA, Bettiol W, Dynia JF: Efeito de aplicações de lodos de esgoto sobre os teores de metais pesados em folhas e grãos de milho. Revista Brasileira de Ciências do Solo 2006, 30:583-594.

35. Sígolo JB, Pinheiro CHR: Lodo de esgoto da ETE Barueri - SP: Proveniência do enxofre elementar e correlações com metais pesados associados. Revista do Instituto de Geociências da Universidade de São Paulo 2010, 10(1):39-51.

36. Singh BR, Agarwal M, Chandra M, Verma M, Sharma G, Verma JC, Singh VP: Plasmid profile and drug resistance pattern of zoonotic Salmonella isolates from Indian buffaloes. Journal of Infection in Developing Countries 2010, 4(8):4477-4483.

37. Fonseca EL, Mykytczuk OL, Asensi MD, Reis EMF, Ferraz LR, Paula FL, Ng LK Rodrigues DP: Clonality and antimicrobial resistance gene profiles of multidrug-resistant Salmonella enterica serovar Infantis isolates from four public hospitals in Rio de Janeiro, Brazil. Journal of Clinical Microbiology 2006, 44(8):2767-2772.

38. Oliveira CJB, Carvalho LFS, Aparecida SF, Tavechio AT, Menezes CCP, Domingues FJJ: Antimicrobial Resistance Salmonella Serotypes Isolated from Slaughter-Age Pigs and Environmental Samples. Microbial Drug Resistance 2002, 8(4):407-411.

39. Parry CM, Threlfall EJ: Antimicrobial resistance in typhoidal and nontyphoidal salmonellae. Current Opinion in Infectious Diseases 2008, 21:531-538.

40. Manios SG, Kontantidinis N, Gounadaki AS, Skandamsi PN: Dynamics of low (1-4cells) vs high populations of Listeria monocytogenes and Salmonella 
Typhimurium in fresh-cut salads and their sterile liquido and solidified extracts. Food Control 2013, 29(2):318-327.

41. Sant'Ana AS, Barbosa NS, Destro MT, Landgraf M, Francos BDGM: Growth potential of Salmonella sp and Listeria monocytogenes in nine types of ready-to-eat vegetables stored at variable temperature conditions during shelf-life. International Journal of Food Microbiology 2012, 157:52-58.

42. Eamens GJ, Waldron AM, Nicholls PJ: Survival of pathogenic and indicator bacteria in biosolids applied to agricultural land. Aust I Soil Res 2006, 44:647-659.

43. Sabesp: Companhia de Saneamento Básico do Estado de São Paulo. 2011. Data obtained with the Engineering Department of this company.

44. United States Environmental Protection Agency: Salmonella in Sewage Sludge (Biosolids) Modified Semisolid Rappaport-Vassiliadis (MSRV). [http://water.epa.gov/scitech/methods/cwa/bioindicators/upload/ 2008_11_25_methods_met_hod_biological_1682.pdf]. (accessed on 12 March 2014)

45. Chapman PA, Ellin M, Ashton R, Shafique W: Comparison of culture, PCR and immunoassays for detecting Escherichia coli 0157 following enrichment culture and immunomagnetic separation performed on naturally contaminated raw meat products. Int J Food Microbiol 2001, 68:11-20.

46. Soumet C, Ermel G, Rose N, Drouin P, Salvat G, Colin P: Evaluation of a Multiplex PCR assay for simultaneous identification of Salmonella sp., Salmonella Enteritidis and Salmonella Typhimurium from environmental swabs of poultry houses. Letters in Applied Microbiology 1999, 28:113-117.

47. Clinical and Laboratory Standards Institute: Performance Standards for Antimicrobial Susceptibility Testing; Nineteenth Informational Supplement Wayne, PA: CLSI Publication M100-S19; 2009

48. Dropa M, Balsalobre LC, Lincopan N, Mamizuka EM, Murakami T, Cassettari VC, Franco F, Guida SM, Balabakis AJ, Passadore LF, Santos SR, Matté GR, Matté MH: Extended-spectrum beta-lactamases among Enterobacteriaceae isolated in a public hospital in Brazil. Revista do Instituto de Medicina Tropical de São Paulo 2009, 51(4):203-209.

49. Clinical and Laboratory Standards Institute: Performance Standards for Antimicrobial Susceptibility Testing; Twenty-First Informational Supplement. Wayne, PA: CLSI Publication M100-S21; 2012.

doi:10.1186/s12866-014-0263-x

Cite this article as: Krzyzanowski et al:: Quantification and characterization of Salmonella spp. isolates in sewage sludge with potential usage in agriculture. BMC Microbiology 2014 14:263.

\section{Submit your next manuscript to BioMed Central and take full advantage of:}

- Convenient online submission

- Thorough peer review

- No space constraints or color figure charges

- Immediate publication on acceptance

- Inclusion in PubMed, CAS, Scopus and Google Scholar

- Research which is freely available for redistribution

Submit your manuscript at www.biomedcentral.com/submit
() Biomed Central 